\title{
Pre-Service Teacher Opinions About Eco- Friendly Person Activity Package Developed to Raise Environmental Awareness
}

\author{
Sevcan CANDAN \\ Kastamonu University, Kastamonu, TURKEY \\ Sinan ERTEN \\ Hacettepe University, Ankara, TURKEY
}

\begin{abstract}
In this study, the effectiveness of Eco-Friendly Person Activity Package developed in order to raise environmental awareness in pre-service teachers and enable them to be an example of an eco-friendly teacher for their future students, and the responses about Eco-Friendly Person Activity Package were investigated. The study was conducted on 75 fourth year pre-service teachers from departments of Elemantary School Education who took Environmental Education Course in a state university during fall semester of the academic year 2014-2015 and 10 pre-service teachers who participated in the study were asked to provide their opinions. It was a qualitative study based on a phenomenological design. Data of this research were obtained using a semi-structured questionnaire and interviews and analyzed with an inductive approach using Nvivo 9 qualitative analysis program. The participants were asked about the environment, environmental problems, future environmental problems, characteristics of an eco-friendly person before and after the implementation and were asked to provide their opinions about Eco-Friendly Person Activity Package after the implementation. Before the implementation, it was identified that the participants had lack of knowledge about the environment, neglected the role of people in environmental problems, could not make realistic estimations about possible future problems and didn't know the requirements of being an eco-friendly person. Following the environmental education provided using EcoFriendly Person Activity Package, the participants made statements indicating that they have a good knowledge of the environment, can describe environmental problems and their causes based on such knowledge, are aware of the fact that the future of the environment will change based on human acts, show positive attitudes, including loving the environment and having concerns about its future, describe an eco-friendly person and show such behaviors. Based on the findings, it was concluded that Eco-Friendly Person Activity Package, which aims to raise examples of eco-friendly teachers, was effective in reaching its target.
\end{abstract}

Keywords: Environmental education, eco-friendly person, pre-service teachers, eco-friendly person activity package

\section{Introduction}

Today, environmental problems increasingly continue, and in order to find solutions to these problems and prevent new problems from emerging, individuals who are aware of environmental problems, can take initiatives on solving them, and know that natural resources may run out have to be raised (Atasoy, 2015; Johnson and Mappin, 2005; Palmer and Neal, 2003; Özdemir, 2010; Sanera and Shaw, 1999). The deterioration of the environment at such rapid rate can only be prevented by individuals who internalize the environment and behaviorally protect it. Environmental education plays a key role

ISSN: 2146-0329

${ }^{*}$ This is a part of the PhD Thesis prepared by Sevcan CANDAN under the supervision of Assoc. Prof. Sinan ERTEN

${ }^{*}$ Corresponding Author: Sevcan CANDAN,

E-mail: scandan@kastamonu.edu.tr 
in developing these protective behaviors towards the environment in individuals. These problems can be solved if personal behaviors are changed. Changing behaviors can only be achieved by changing knowledge and standards of judgment so environmental education is required to develop positive attitudes and values towards the environment (Erten, 2005, 2008; Çağlar, 2011).

Beyond being a particular section and subject of general education systems, environmental education is an area of practice in which the will and skills to live in harmony with the environment are developed. (Özdemir, 2010). Environmental education addresses students' cognitive, affective and psycho-motor learning areas (Erten, 2004). Moreover, environmental education aims to raise individuals with environmental awareness who know themselves, develop sensitivity towards the environment and thus are at peace with themselves (Wilson, 1996).

Environmental awareness can be defined as developing environmental knowledge, positive attitudes and environmentally responsible behavior (Erten, 2012). Environmental knowledge, positive attitudes and environmentally responsible behavior should be considered as three requirements or components of environmental awareness (Erten, 2012). Environmental knowledge, one of three components of environmental awareness, represent ecological knowledge. An environmentally conscious individual should be aware of the function in nature and importance of the thing s/he will protect. Positive Attitude towards the Environment, which is the second component, can be defined as feelings caused by environmental issues, attitudes towards environmental issues and the enthusiasm shown for the solution of these problems. The last component is Environmentally Responsible Behaviors. Environmentally responsible behavior of an individual is defined as individual's transforming environmental knowledge and positive attitudes towards the environment into behavior and engaging in actions that benefit the environment. Environmental awareness is a combination of all these and the lack of one of the components destroys an individual's environmental awareness (Erten, 2004, 2005, 2006; Erten and Aydoğdu, 2011).

The purpose of the training activities carried out to improve the environmental awareness is to inform individuals about environmental issues, and then try to ensure that such awareness turns into concrete behavior and becomes permanent through various activities, however, an attitude contrary to these requirements is shown in Turkey (Çağlar, 2011). It is known that an environmental education approach which points out to universal characteristics of the environment, provides facilities for individuals to observe and accurately perceive the nature, ensures that the sense of environmental protection is internalized and education services are provided to that effect (Cağlar, 2011; Foster and Magdoff, 2011). Considering that higher education institutions aim to raise individuals with qualifications that will advance the society's quality of life, it is a fact that these institutions are responsible for upbringing of the next generations with environmental awareness in order to fight with environmental problems, which threaten the quality of life on a global scale. Therefore, it is known that environmental education should target higher education students (Johnson and Mappin, 2005). Only a teacher showing eco-friendly behaviors can raise awareness about the environment in new generations so pre-service teachers are separated from the students from other higher education institutions (Güler, 2009; Lewin-Benham, 2006; Malone and Tranter, 2003; Phenice and Griffore, 2003). The common point between eight main headings specified by Environmental Protection Agency (EPA) for achievement in environmental education in formal education, environmental education stages of the North American Association of Environmental Education (NAAEE), the requirement for teacher training for environmental education (Glasgow, 1994), and the 
environmental education model developed by Hungerford and Peyton (1994) and published in cooperation with UNESCO International Environmental Education Program (IEEP) is that increasing the quality of a teacher who will provide environmental education is essential.

Various investigations identified that environmental education facilitates turning knowledge into behavior, becomes more permanent, and allows development of positive attitudes towards the environment and acquisition of values, when it is performed using activities that involve one-to-one interaction with the environment (Erten, 2004; Farmer, Knapp and Benton, 2007; Ozaner, 2004). Organizing and environmental education with the same goals for pre-service teachers is thought to be effective in raising teachers who internalized environmental education. For this purpose, the Eco-Friendly Person Activity Package (EFPAP) was developed by the researcher in order to introduce environmental awareness to pre-service teachers.

The purpose of EFPAP is to make pre-service teachers be aware that the environment is not a thing which doesn't include them, that on the contrary, they are part of the environment and to make them acquire environmentally friendly behaviors. If the objective is to develop new environmentally friendly behaviors environmental behaviors in pre-service teachers, it is necessary to ensure that they experience such behaviors (Kollmus and Agyeman, 2010). This is the main reason for the preparation of the activity package. EFPAP activities are based on a variety of teaching methods and techniques. The implementation covers a 14-week process and consists of 15 activities. The implementation conducted using a variety of teaching methods is thought to serve the desired goal. EFPAP, which aims to bring environmental awareness to pre-service teachers and ensure that they become examples of an ecofriendly individual for their future students, was developed as an implementation proposal for Environmental Education Courses, which are taught uniformly in universities. With this aspect, it is expected to contribute to the literature. It is also thought to shed light on further practices and research on the necessity and effectiveness of alternative environmental education practices. Thus, the purpose of this study is to determine the effectiveness of EFPAP, which aims to provide preservice teachers with environmental knowledge, positive environmental attitude, and beneficial environmental behavior, in improving ecological knowledge, environmental sensitivity, and responsible environmental behavior among pre-service teachers. It also intends to examine student views concerning the effectiveness of EFPAP. The study sought answers to the following questions:

1) What do pre-service teachers think about the environment, environmental issues and future environmental problems before and after the implementation?

2) What do pre-service teachers think about an eco-friendly person before and after the implementation?

3) What do pre-service teachers think about EFPAP?

\section{Methodology}

This study was conducted in the field of social sciences using qualitative research design. Qualitative research is carried out in a study process which involves the determination of perceptions and events in a clear and holistic way in their own environment (Coolican, 2009; Mayring, 2000). The structure of this study, conducted to determine individuals' thoughts and perspectives, and how they interpret an event, is consistent with phenomenological design, one of qualitative research designs. Phenomenology is a method depicting what is visible, based on individuals' 
descriptions of their experiences (Larkin, Watts and Clifton, 2006). Studies conducted using this method are intended to determine the mental configurations of individuals and the facts disguised.

Study Group

This study was conducted on 75 fourth year pre-service teachers from departments of Elemantary School Education who took Environmental Education Course in a state university during fall semester of the academic year 2014-2015. Of such pre-service teachers, 10 were asked to provide their opinions before and after the implementation. The participants were selected in a manner that would reflect the study group, and the selection criteria were academic average, age and gender. The participants' characteristics were as follows: academic average: 2.02-3.62; equal number of females and males; age: in the range of 22 to 24 years. The participants were coded using the following letters: $A, B, C, D, E, F, G, H, I$ and $J$.

Table 1.

The participants' characteristics

\begin{tabular}{lcccccccccc}
\hline Department & ESE $^{*}$ & ESE & ESE & ESE & ESE & ESE & ESE & ESE & ESE & ESE \\
\hline $\begin{array}{l}\text { Academic } \\
\text { Average }\end{array}$ & 2.02 & 3.62 & 2.86 & 3.54 & 3.57 & 2.34 & 2.2 & 2.67 & 2.94 & 2.43 \\
\hline Age & 22 & 22 & 24 & 23 & 23 & 24 & 23 & 24 & 23 & 22 \\
\hline Gender & $F^{* *}$ & F & F & F & F & M $^{* *}$ & M & M & M & M \\
\hline Participant & A & B & C & D & E & F & G & H & I & J \\
\hline${ }^{*}$ Elemantary School Education, ${ }^{* *}$ Female, ${ }^{* * *}$ Male & & & & &
\end{tabular}

\section{Implementation Process}

The study took 16 weeks and the first and last weeks of this period was allocated to implementation of data collection tools. Therefore, it took 14 weeks to apply EFPAP activities. During the first three weeks of the implementation process, the researcher provided ecological information and described the activities in the activity package to the pre-service teachers. In the case of the activities during the 10-week period between fourth and thirteenth weeks, the s pre-service teachers assumed the whole responsibility. The role of the researcher in this process was guidance. The participants were asked to be divided into 10 groups in which they would work with the participants they'd like to work with. Between fourth and thirteenth weeks' activities were assigned to these 10 groups by lot. A trip to an environment-oriented center was the final stage of the activity package. The implementation period was completed with final interviews made with the pre-service teachers during the last week. A scoring tool developed by the researcher was used to evaluate the pre-service teachers' products related to the activities. Table 2 shows the content of EFPAP and information about weekly schedule of the implementation. 
Table 2.

Activities in eco-friendly person activity package and their coverage

\begin{tabular}{|c|c|c|c|}
\hline Weeks & $\begin{array}{l}\text { Implementation } \\
\text { Process of } \\
\text { EFPAP } \\
\text { Activities }\end{array}$ & Activity Coverage & $\begin{array}{l}\text { Teaching } \\
\text { Methods and } \\
\text { Techniques } \\
\text { Used }\end{array}$ \\
\hline 1. & $\begin{array}{l}\text { Ecological } \\
\text { Information-I } \\
\text { (Living and } \\
\text { Nonliving } \\
\text { Things) }\end{array}$ & $\begin{array}{l}\text { The first stage of a 3-stage powerpoint } \\
\text { presentation on ecological information, which } \\
\text { is a component of environmental awareness, } \\
\text { is introduced. Information about living and } \\
\text { nonliving things, the subconcepts of the } \\
\text { environment concept, is given. }\end{array}$ & Simple lecturing \\
\hline 2. & $\begin{array}{l}\text { Ecological } \\
\text { Information-II } \\
\text { (The Concepts } \\
\text { of Balance and } \\
\text { Interaction) }\end{array}$ & $\begin{array}{l}\text { In this section, which is the second stage of } \\
\text { the presentation, ecological relations and } \\
\text { matter cycles are described. Environmental } \\
\text { problems arising from the changes in the } \\
\text { environment are discussed. }\end{array}$ & $\begin{array}{l}\text { Simple lecturing } \\
\text { Large Group } \\
\text { Discussion }\end{array}$ \\
\hline 3. & $\begin{array}{l}\text { Ecological } \\
\text { Information-III } \\
\text { (Environmental } \\
\text { Problems and } \\
\text { Environmental } \\
\text { Education) }\end{array}$ & $\begin{array}{l}\text { At this stage, information about } \\
\text { environmental problems, environmental } \\
\text { education required to solve these problems } \\
\text { and environmental awareness, which } \\
\text { environmental education aims to raise in } \\
\text { individuals. Newspaper reports about } \\
\text { environmental problems from Turkey and } \\
\text { abroad are shown and discussed. The pre- } \\
\text { service teachers are asked to make } \\
\text { recommendations for solution of the } \\
\text { problems and the concept of environmental } \\
\text { education is emphasized. }\end{array}$ & $\begin{array}{l}\text { Simple lecturing } \\
\text { Large Group } \\
\text { Discussion } \\
\text { Question-Answer } \\
\text { Problem Solving }\end{array}$ \\
\hline 4. & Fixing Taps & $\begin{array}{l}\text { The aim of the activity, fixing taps, which was } \\
\text { developed as an activity to raise } \\
\text { environmental awareness, was to develop } \\
\text { knowledge and skill about water saving. Tap, } \\
\text { types of tap, causes of waste of water from } \\
\text { tap and how to fix such tap are demonstrated } \\
\text { to this group of pre-service teachers. }\end{array}$ & $\begin{array}{l}\text { Demonstration } \\
\text { Project }\end{array}$ \\
\hline 5. & Paper Making & $\begin{array}{l}\text { Recycling, paper recycling, environmental } \\
\text { benefits of paper recycling and steps of paper } \\
\text { recycling; the pre-service teachers produce a } \\
\text { piece of new (recycled) paper using waste } \\
\text { papers in paper recycling bins. The stages of } \\
\text { making recycled paper are compared with } \\
\text { the stages in paper recycling plants. They } \\
\text { generate a product from the recycled paper. }\end{array}$ & $\begin{array}{l}\text { Simple lecturing } \\
\text { Demonstration } \\
\text { Project }\end{array}$ \\
\hline 6. & $\begin{array}{l}\text { Environment in } \\
\text { the Past and } \\
\text { Environmental } \\
\text { Education }\end{array}$ & $\begin{array}{l}\text { A description plan in which the following } \\
\text { questions are answered and discussed with } \\
\text { other groups is planned: "First Emergence of } \\
\text { the Concept of Environment, Environmental } \\
\text { Practices in All Societies from Past to } \\
\text { Present, Value attached to the Environment } \\
\text { and Causes of Emergence of the Concept of } \\
\text { Environmental Education, Its Position Today } \\
\text { and Its Objectives" }\end{array}$ & $\begin{array}{l}\text { Simple lecturing } \\
\text { Large Group } \\
\text { Discussion } \\
\text { Question-Answer }\end{array}$ \\
\hline 7. & Utilizing Waste & $\begin{array}{l}\text { The students generate minimum } 10 \text { practical } \\
\text { unique products from waste materials which } \\
\text { are considered trash and group such }\end{array}$ & $\begin{array}{l}\text { Demonstration } \\
\text { Discussion } \\
\text { Project }\end{array}$ \\
\hline
\end{tabular}




\begin{tabular}{|c|c|c|c|}
\hline & & $\begin{array}{l}\text { materials as recyclable and nonrecyclable } \\
\text { materials. }\end{array}$ & \\
\hline 7. & $\begin{array}{l}\text { Making a Clock } \\
\text { from Waste }\end{array}$ & $\begin{array}{l}\text { In this activity, which is dedicated to utilizing } \\
\text { waste materials, in addition to the activity of } \\
\text { utilizing wastes, an operating system is made } \\
\text { by adding a clock mechanism to waste } \\
\text { materials. }\end{array}$ & Project \\
\hline 8. & $\begin{array}{l}\text { Research at Bus } \\
\text { Terminal }\end{array}$ & $\begin{array}{l}\text { In this activity, a bus service of a bus } \\
\text { company at intercity bus terminal is selected } \\
\text { and the amount of waste generated during } \\
\text { that bus service is calculated. Then, weekly, } \\
\text { monthly and annual amounts of waste using } \\
\text { total number of bus services of the terminal } \\
\text { are calculated. Details about financial values } \\
\text { of such amounts are also obtained. } \\
\text { Executives of the company related to the } \\
\text { selected bus service are met and details } \\
\text { about how such waste is left in the } \\
\text { environment are obtained. Each individual } \\
\text { produces a solution to reducing and utilizing } \\
\text { such waste. }\end{array}$ & $\begin{array}{l}\text { Discussion } \\
\text { Problem Solving } \\
\text { Case Study } \\
\text { Observation } \\
\text { Interview }\end{array}$ \\
\hline 9. & $\begin{array}{l}\text { Worldwide } \\
\text { practices about } \\
\text { the environment }\end{array}$ & $\begin{array}{l}\text { All congresses and conferences held about } \\
\text { the environment is described by grouped pre- } \\
\text { service teachers. Objectives of the } \\
\text { conferences; whether they are effective today } \\
\text { or not and to what extent they achieve their } \\
\text { objectives are discussed. }\end{array}$ & $\begin{array}{l}\text { Simple lecturing } \\
\text { Large Group } \\
\text { Discussion } \\
\text { Question-Answer }\end{array}$ \\
\hline 10. & Sustainability & $\begin{array}{l}\text { In-depth information is provided about the } \\
\text { concept of sustainability, which is also } \\
\text { mentioned and defined in environmental } \\
\text { agreements made worldwide. Information } \\
\text { about sustainability is provided and practices } \\
\text { under the name of sustainability in the city } \\
\text { where the pre-service teachers live, Turkey } \\
\text { and the world are interpreted. }\end{array}$ & $\begin{array}{l}\text { Simple lecturing } \\
\text { Large Group } \\
\text { Discussion } \\
\text { Question-Answer }\end{array}$ \\
\hline 11. & $\begin{array}{l}\text { Carbon } \\
\text { Footprint and } \\
\text { Ecological } \\
\text { Footprint }\end{array}$ & $\begin{array}{l}\text { Information is provided about the emergence } \\
\text { of carbon and ecological footprints, their } \\
\text { implications and what such implications } \\
\text { mean. All pre-service teachers individually } \\
\text { perform Carbon and Ecological Footprint } \\
\text { tests and share the results. What can be } \\
\text { done to reduce footprints is interpreted and } \\
\text { discussed. }\end{array}$ & $\begin{array}{l}\text { Simple lecturing } \\
\text { Large Group } \\
\text { Discussion } \\
\text { Question-Answer }\end{array}$ \\
\hline 12. & Solar Cells & $\begin{array}{l}\text { The concept of renewable energy is } \\
\text { introduced. Information about solar cells, } \\
\text { operation principles of solar cells and areas } \\
\text { of application of solar cells is provided. } \\
\text { Minimum } 5 \text { products with effective practices } \\
\text { in daily life are designed using solar cells. }\end{array}$ & $\begin{array}{l}\text { Simple lecturing } \\
\text { Demonstration } \\
\text { Project }\end{array}$ \\
\hline
\end{tabular}




\begin{tabular}{|c|c|c|c|}
\hline 13. & $\begin{array}{l}\text { Waste Burial } \\
\text { Activity }\end{array}$ & $\begin{array}{l}\text { For this activity, in the first week, the pre- } \\
\text { service teachers dig a hole and bury the } \\
\text { waste they've collected from the environment } \\
\text { and this burial is opened in the last week. } \\
\text { The pre-service teachers must group the } \\
\text { waste they've buried, estimate the changes } \\
\text { that would take place over time, and test the } \\
\text { validity of such estimates by comparing them } \\
\text { with the wastes they've buried. They prepare } \\
\text { a presentation on the causes of } \\
\text { transformation and the reasons for the fact } \\
\text { that no transformation has taken place and } \\
\text { share it with other groups. }\end{array}$ & $\begin{array}{l}\text { Observation } \\
\text { Problem Solving } \\
\text { Project } \\
\text { Discussion }\end{array}$ \\
\hline 14. & Trip & $\begin{array}{l}\text { A trip to a water treatment plant, a solid } \\
\text { waste treatment plant or a recycling plant is } \\
\text { organized. The destination should either be a } \\
\text { structure providing benefits to the } \\
\text { environment or a business in which recycling } \\
\text { is performed. Before the trip, a trip form is } \\
\text { distributed to the pre-service teachers to } \\
\text { investigate their observations and knowledge } \\
\text { expected from them and the pre-service } \\
\text { teachers are asked to complete and return } \\
\text { the form at the end of the trip. }\end{array}$ & $\begin{array}{l}\text { Trip } \\
\text { Observation } \\
\text { Discussion }\end{array}$ \\
\hline
\end{tabular}

\section{Data Collection}

Interviews of the study were conducted using a semi-structured interview form before the implementation and in the form of semi-structured interviews, carried out by adding a question to the existing interview form after the implementation. The interview questions were prepared under the supervision of an academic researcher specializing on qualitative studies. Before the study data were collected, preliminary interviews were made with 5 third year pre-service teachers from department of Science Education of a state university, other than the one in which the implementation was carried out. By taking account of the criteria that the pre-service teachers can give answers about their gains and experiences related to the activities, necessary revisions were made in interview questions and the questions were finalized at the end. The only difference between pre- and post-implementation interview questions is the extra question in the post-implementation questions, which asks the student to evaluate EFPAP. The interviews lasted 15-20 minutes. Inretview questions are given in Table 3. 
Table 3.

\section{Interview questions}

Pre-implementation Interview questions

1. What do you think about the environment?

2. There are environmental problems caused by some deterioration in the environment. What do you think these are?

*What kind of change do you think the existing environmental problems in Turkey will undergo 50 years from now?

3. In our lessons in this semester, we'll carry out Eco-Friendly Person Activities. How would you describe an eco-friendly person?

* How would you describe the characteristics of an eco-friendly person?

* What does s/he have to know?

* How should s/he act?

* How should s/he behave?

Post-implementation Interview questions

1. What do you think about the environment? What do you think these are?

2. There are environmental problems caused by some deterioration in the environment. What do you think these are?

*What kind of change do you think the existing environmental problems in Turkey will undergo 50 years from now?

3. In our lessons in this semester, we carried out Eco-Friendly Person Activities. How would you describe an eco-friendly person?

${ }^{*}$ How would you describe the characteristics of an eco-friendly person?

* What does s/he have to know?

* How should s/he act?

* How should s/he behave?

4. How did your friends appear to you before, during and after the lesson? What kind of changes did you observe?

*What did you gain from this lesson? I'll ask you to evalute.

\section{Validity and Reliability Studies}

In order to ensure validity and reliability of the study, the participants and the researcher's work were videotaped throughout the implementation. Two experts were asked to examine these records. Moreover, two weeks of the implementation process were observed by two experts. Pre-service teachers' consents to videotaping of the interviews were obtained using a volunteer form and such consent was also obtained verbally before the interview. The interview was carried out in the presence of the interviewee and the researcher only.

\section{Data Analysis}

Study data were analyzed using content analysis method. Content analysis involves summarizing and indicating basic contents of the available written documents and the messages they contain (Cohen, Manion and Morrison, 2007). Content analysis consisted of four stages, including processing qualitative study data obtained from the documents, coding data, finding themes, arranging codes and themes, describing and interpreting findings (Yıldırım and Şimşek, 2006). For the first stage, audio records and interview forms were transformed into written form in the computer environment without changing them. a total of 77 pages of written documents, including 23 pages before the implementation and 54 pages after the implementation, were obtained. Interview data, which was transferred to digital form without making any change, was reviewed by another researcher and deciphered records of the interview were cleared from daily colloquial language to make them suitable for analysis and arranged to 
make them understandable (Coolican, 2009; Kvale, 1996). Then the interview was rearranged according to documentation rules (Mayring, 2000). Nvivo 9 program was used to analyze deciphered interview records. Data was analyzed using inductive analysis. Data was independently read by the author and qualitative study expert, and individual codes and categories were created. These individual codes and categories were compared and the records were examined until a consensus was reached. Intercoder reliability coefficient proposed by Miles and Huberman (1994) was used to determine the reliability of the study. Compliance percentage was calculated using the following formula: reliability $(r)=$ (Consensus) / (Consensus + Disseensus) $X 100$. Calculated compliance percentage was 91.03. Coding and categorization were performed before and after the implementation for each study problem and the findings were presented by including extracts.

\section{Results and Discussion}

Codes and categories obtained from the study are presented by giving pre- and postimplementation data in the same table. This tabulation method was thought to be effective so that the findings can be concretely understood. In this context, pre-service teachers' statements during the interviews are also included. The study results are listed under headings.

\section{Results about the description of the environment}

References and codes related to the opinions of the pre-service teachers from the study group about the environment are given in Table 4. 
Table 4.

Coding and category densities of pre-service teachers' opinions about the environment before and after the implementation

\begin{tabular}{|c|c|c|c|c|c|c|c|c|c|}
\hline \multirow{2}{*}{\multicolumn{5}{|c|}{$\begin{array}{c}\text { Number of References and Coding Density of } \\
\text { Before the Implementation }\end{array}$}} & he Participa & Opinions Abo & t the & Envirc & ment \\
\hline & & & & & \multicolumn{5}{|c|}{ After the Implementation } \\
\hline $\begin{array}{l}\text { ते } \\
\text { D্ } \\
\frac{\Phi}{\pi} \\
0\end{array}$ & $\frac{0}{8}$ & "ror & 㐫 & $\begin{array}{l}\stackrel{\circ}{0} \\
0\end{array}$ & $\begin{array}{l}\text { ते } \\
\text { Dे } \\
\stackrel{\Phi}{*} \\
0\end{array}$ & $\frac{1}{8}$ & $\frac{{ }^{*} \frac{r}{0}}{2}$ & ฮั & $\frac{\widehat{a}}{0}$ \\
\hline \multirow[t]{10}{*}{ Living } & \multirow[t]{3}{*}{$\begin{array}{l}\text { Human } \\
\text { beings }\end{array}$} & \multirow[t]{3}{*}{5} & \multirow[t]{3}{*}{17.2} & \multirow[t]{10}{*}{68.9} & \multirow[t]{4}{*}{ Living } & $\begin{array}{l}\text { Human } \\
\text { beings }\end{array}$ & 10 & 10.6 & \multirow[t]{4}{*}{37.2} \\
\hline & & & & & & Animals & 9 & 9.5 & \\
\hline & & & & & & Plants & 10 & 10.6 & \\
\hline & \multirow[t]{4}{*}{ Animals } & \multirow[t]{4}{*}{8} & \multirow[t]{4}{*}{27.5} & & & Biotic & 6 & 6.3 & \\
\hline & & & & & \multirow[t]{3}{*}{ Nonliving } & Earth & 8 & 8.5 & \multirow[t]{3}{*}{25.5} \\
\hline & & & & & & Water & 7 & 7.4 & \\
\hline & & & & & & Sun & 9 & 9.5 & \\
\hline & \multirow[t]{3}{*}{ Trees } & \multirow[t]{3}{*}{7} & \multirow[t]{3}{*}{24.1} & & \multirow[t]{3}{*}{ Balance } & Water cycle & 5 & 5.3 & \multirow[t]{3}{*}{16} \\
\hline & & & & & & $\begin{array}{l}\text { Oxygen } \\
\text { cycle }\end{array}$ & 7 & 7.4 & \\
\hline & & & & & & $\begin{array}{l}\text { Phosphorus } \\
\text { cycle }\end{array}$ & 3 & 3.1 & \\
\hline \multirow[t]{3}{*}{$\begin{array}{l}\text { Non- } \\
\text { living }\end{array}$} & \multirow[t]{3}{*}{ Environment } & \multirow[t]{3}{*}{9} & \multirow[t]{3}{*}{31} & \multirow[t]{3}{*}{31.1} & \multirow[t]{3}{*}{ Intercation } & $\begin{array}{l}\text { Human- } \\
\text { Human }\end{array}$ & 8 & 8.5 & \multirow[t]{3}{*}{21.3} \\
\hline & & & & & & $\begin{array}{l}\text { Animal- } \\
\text { Human }\end{array}$ & 7 & 7.4 & \\
\hline & & & & & & $\begin{array}{l}\text { Animal- } \\
\text { Animal }\end{array}$ & 5 & 5.3 & \\
\hline
\end{tabular}

In view of the study data, there is a clear difference between the pre-service teachers' opinions about the environment before and after the implementation. Before the implementation, most of the participants represented the environment using living things such as human beings, animals or trees they see around them. As nonliving things, they showed the place where they live as the environment. It was seen that their description of the environment is incomplete. Before the implementation, the participants' statements were as follows:

"The environment is the space where my house is." (Preimplementation Interview A)

"It is the place [=space] where I[=human being], animals, trees live." (Pre-implementation Interview H)

After the implementation, it was seen that the participants could refer to living things, nonliving things, the relationship between living things, that the system comprised of these things is in a balance and some factors providing this balance, while describing the environment. There were also differences between codings in Living and Nonliving categories before and after the implementation. Codes of nonliving category do not represent clarity, whereas 
codes after the implementation are much clearer. The participants defined the environment using statements about the things comprising the environment, that these things are in balance by matter cycles and that this entire system is in an interaction. The implementation can be said to be useful in helping the pre-service teachers define the environment and the components of the environment. After the implementation, the participants' statements were as follows:

"It is a place where there are human beings, animals, plants, water and earth...interaction...where these creatures live in balance." (Post-implementation Interview C)

"In the environment, human beings are affected by what human beings do [=human-human]." (Post-implementation Interview A)

"There is a balance in the environment...the balance is provided by lion eating gazelle [=animal-animal]." (Post-implementation Interview E)

\section{Results About Existing and Future Environmental Problems}

The participants' descriptions and opinions of the environmental problem are given in Table 5. 
Table 5.

Coding and category densities of pre-service teachers' opinions about the environmental problems before and after the implementation

\begin{tabular}{|c|c|c|c|c|c|c|c|c|c|}
\hline \multicolumn{10}{|c|}{$\begin{array}{l}\text { Number of References and Coding Density of the Participants' Opinions about the } \\
\text { Environmental Problems }\end{array}$} \\
\hline \multicolumn{5}{|c|}{ Before the Implementation } & \multicolumn{5}{|c|}{ After the Implementation } \\
\hline $\begin{array}{l}7 \\
0 \\
0 \\
\frac{0}{\pi} \\
0\end{array}$ & $\frac{0}{0}$ & ${ }^{*}$ r & oั & $\begin{array}{l}\widehat{o} \\
\text { o }\end{array}$ & $\begin{array}{l}3 \\
0 \\
0 \\
\frac{\Phi}{\pi} \\
0\end{array}$ & $\frac{0}{8}$ & ${ }^{*} \frac{r}{0}$ & 文 & $\begin{array}{l}\frac{0}{0} \\
0\end{array}$ \\
\hline \multirow{9}{*}{$\begin{array}{l}\text { Air } \\
\text { pollution }\end{array}$} & \multirow{3}{*}{$\begin{array}{l}\text { Use of } \\
\text { coal }\end{array}$} & \multirow{3}{*}{11} & \multirow{3}{*}{20.} & \multirow{9}{*}{$\begin{array}{l}59 . \\
2\end{array}$} & \multirow{4}{*}{ Air pollution } & Use of vehicles & $\begin{array}{l}1 \\
4\end{array}$ & 7.9 & \multirow[t]{4}{*}{28.1} \\
\hline & & & & & & Use of coal & $\begin{array}{l}1 \\
2\end{array}$ & 6.7 & \\
\hline & & & & & & Factory wastes & 9 & 5.1 & \\
\hline & \multirow{3}{*}{$\begin{array}{l}\text { Factory } \\
\text { wastes }\end{array}$} & \multirow{3}{*}{8} & \multirow{3}{*}{$\begin{array}{l}14 . \\
8\end{array}$} & & & Use of oil & $\begin{array}{l}1 \\
5\end{array}$ & 8.4 & \\
\hline & & & & & \multirow{3}{*}{$\begin{array}{l}\text { Water } \\
\text { pollution }\end{array}$} & $\begin{array}{l}\text { Contamination by } \\
\text { pesticides }\end{array}$ & $\begin{array}{l}1 \\
1\end{array}$ & 6.2 & 16.8 \\
\hline & & & & & & Waste & 4 & 2.2 & \\
\hline & \multirow{3}{*}{$\begin{array}{l}\text { Felling } \\
\text { trees }\end{array}$} & \multirow{3}{*}{13} & \multirow{3}{*}{24} & & & Detergents & $\begin{array}{l}1 \\
5\end{array}$ & 8.4 & \\
\hline & & & & & \multirow{2}{*}{$\begin{array}{l}\text { Radioactive } \\
\text { pollution }\end{array}$} & Nuclear explosions & 9 & 5.1 & \multirow[t]{2}{*}{13.5} \\
\hline & & & & & & Base station & $\begin{array}{l}1 \\
5\end{array}$ & 8.4 & \\
\hline \multirow{3}{*}{$\begin{array}{l}\text { Ozone } \\
\text { layer } \\
\text { depletion }\end{array}$} & \multirow{3}{*}{$\begin{array}{l}\text { Deodoran } \\
\mathrm{t}\end{array}$} & \multirow{3}{*}{5} & \multirow{3}{*}{9.2} & \multirow{3}{*}{9.3} & \multirow{2}{*}{$\begin{array}{l}\text { Global } \\
\text { warming }\end{array}$} & Melting of icebergs & 8 & 4.5 & \multirow[t]{2}{*}{9.6} \\
\hline & & & & & & Greenhouse gas & 9 & 5.1 & \\
\hline & & & & & \multirow{2}{*}{$\begin{array}{l}\text { Soil } \\
\text { pollution }\end{array}$} & Plastic & $\begin{array}{l}1 \\
2\end{array}$ & 6.7 & 14 \\
\hline \multirow{5}{*}{$\begin{array}{l}\text { Soil } \\
\text { pollution }\end{array}$} & \multirow{2}{*}{$\begin{array}{l}\text { Domestic } \\
\text { wastes }\end{array}$} & \multirow[b]{2}{*}{13} & \multirow[b]{2}{*}{24} & \multirow{5}{*}{$\begin{array}{l}31 . \\
5\end{array}$} & & Pesticide & $\frac{6}{7}$ & $\frac{3.4}{39}$ & \\
\hline & & & & & \multirow{4}{*}{$\begin{array}{l}\text { Behavior of } \\
\text { a non eco- } \\
\text { friendly } \\
\text { person }\end{array}$} & Failure to separate & 6 & 34 & \multirow[t]{4}{*}{17.9} \\
\hline & & & & & & $\begin{array}{l}\text { Failure to allocate } \\
\text { papers to recycling }\end{array}$ & $\begin{array}{l}1 \\
2\end{array}$ & 6.7 & \\
\hline & Chemical & 4 & 7.4 & & & Waste of electricity & 4 & 2.2 & \\
\hline & & & & & & $\begin{array}{l}\text { High consumption } \\
\text { of water }\end{array}$ & $\begin{array}{l}1 \\
0\end{array}$ & 5.6 & \\
\hline
\end{tabular}

"Number of References " Coding Density

In view of Table 5, it appears that the participants' opinions about the environmental problems before the implementation are concentrated in the categories Air Pollution, Soil Pollution and Ozone Layer Depletion. The environmental problems indicated by the participants are visible problems which directly affect human beings today. From the participants' statements, it can be concluded that they did not have adequate level of knowledge on environmental problems. In view of the participants' opinions after the implementation, it appears that the categories in which directly felt effects are referred to as environmental problems are detailed and diversified. Additionally, the participants also indicated the behaviors of non eco-friendly people as an environmental problem. Negative behaviors of people which affect the 
environment were seen as an environmental problem and referred to with the category Behavior of an Non Eco-Friendly Person. The participants defined felling trees because of the failure to effectively ensure recycling of papers as an environmental problem and referred to individuals who act this way as non eco-friendly persons. Another significant point in the findings was that the participants only referred to environmental problems with visible effects which are effective today before the implementation, whereas they also referred to behaviors which have the potential to become an environmental problem when their effects increase, after the implementation. Examples of such references include the problem of water shortage caused by lack of awareness on water consumption, types of pollution caused by failure to separate plastics for recycling or long-term damages to the country caused by waste of electricity. In other words, the participants began to think about the future of the environmental problems.

Codes and categories about the participants' opinions of the change in environmental problems in the future are given in Table 6. 
Table 6.

Coding and category densities of pre-service teachers' opinions about future environmental problems before and after the implementation

\begin{tabular}{|c|c|c|c|c|c|c|c|c|c|}
\hline \multicolumn{10}{|c|}{$\begin{array}{l}\text { Number of References and Coding Density of the Participants' Opinions about Future } \\
\text { Environmental Problems }\end{array}$} \\
\hline \multicolumn{5}{|c|}{ Before the Implementation } & \multicolumn{5}{|c|}{ After the Implementation } \\
\hline 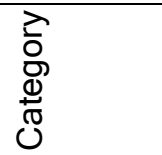 & $\frac{0}{8}$ & "ror & $\frac{\text { o }}{0}$ & $\frac{a}{0}$ & 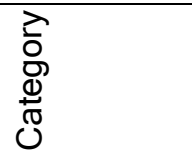 & $\frac{\pi}{8}$ & ${ }^{*} \frac{1}{0}$ & $\frac{\text { o }}{0}$ & $\begin{array}{l}\frac{0}{0} \\
0\end{array}$ \\
\hline \multirow{11}{*}{$\begin{array}{l}\text { Negative } \\
\text { Change }\end{array}$} & \multirow[t]{3}{*}{ Cancer } & \multirow[t]{3}{*}{18} & \multirow[t]{3}{*}{56.3} & \multirow[t]{11}{*}{90.6} & \multirow{6}{*}{$\begin{array}{l}\text { Conditional } \\
\text { Positive } \\
\text { Change }\end{array}$} & Recycling & 8 & 10.1 & 41.8 \\
\hline & & & & & & $\begin{array}{l}\text { Environmental } \\
\text { awareness }\end{array}$ & 5 & 6.3 & \\
\hline & & & & & & $\begin{array}{l}\text { Environmental } \\
\text { education }\end{array}$ & 4 & 5.1 & \\
\hline & \multirow{2}{*}{$\begin{array}{l}\text { Living things } \\
\text { which } \\
\text { underwent } \\
\text { mutation }\end{array}$} & \multirow[t]{2}{*}{1} & \multirow[t]{2}{*}{3.1} & & & $\begin{array}{l}\text { State placing } \\
\text { emphasis on } \\
\text { its citizens }\end{array}$ & 7 & 8.9 & \\
\hline & & & & & & $\begin{array}{l}\text { Protection of } \\
\text { animals }\end{array}$ & 6 & 7.6 & \\
\hline & \multirow[t]{3}{*}{ Death } & \multirow[t]{3}{*}{7} & \multirow[t]{3}{*}{21.8} & & & Afforestation & 3 & 3.8 & \\
\hline & & & & & \multirow[t]{8}{*}{$\begin{array}{l}\text { Negative } \\
\text { Change }\end{array}$} & $\begin{array}{l}\text { Water } \\
\text { shortage }\end{array}$ & 5 & 6.3 & 58.2 \\
\hline & & & & & & $\begin{array}{l}\text { Melting of } \\
\text { icebergs }\end{array}$ & 3 & 3.8 & \\
\hline & Breathlessness & 3 & 9.4 & & & $\begin{array}{l}\text { Extinction of } \\
\text { living things }\end{array}$ & 5 & 6.3 & \\
\hline & & & & & & Pollution & 12 & 15.2 & \\
\hline & & & & & & Disease & 9 & 11.4 & \\
\hline \multirow{3}{*}{$\begin{array}{l}\text { No } \\
\text { Change }\end{array}$} & \multirow{3}{*}{$\begin{array}{l}\text { Being } \\
\text { same }\end{array}$} & \multirow[t]{3}{*}{3} & \multirow[t]{3}{*}{9.4} & \multirow[t]{3}{*}{9.4} & & War & 8 & 10.1 & \\
\hline & & & & & & $\begin{array}{l}\text { Scarcity } \\
\text { food }\end{array}$ & 5 & 6.3 & \\
\hline & & & & & & $\begin{array}{l}\text { Climate } \\
\text { change }\end{array}$ & 4 & 5.1 & \\
\hline
\end{tabular}

The majority of the participants stated that the environmental problems would be negative in the future before the implementation. It is seen that they think the environmental problems 50 years from now would only affect the living things. Their statements on such affects included breathlessness because of air pollution and increase in cancer. One of the participants said that the effects of environmental problems would manifest themselves as creating living things which have undergone mutation in the future. This statement was interpreted as the fact that the participant was far from the reality caused by lack of knowledge about the environment. Some of the participants stated that there'd be no change in environmental problems and no increase in the intensity or the number of the problems. Such statements were thought to be a result of the lack of knowledge on the factors affecting the environmental problems and ecological knowledge about the environment. The participants' statements before the implementation were as follows: 
"There'll be too much cancer in the future; there'll be deaths caused by the environment "(Pre-implementation Interview B)

"Animals will undergo mutations because of the changes in the environment."(Pre-implementation Interview D)

It is seen that post-implementation participant opinions were concentrated by approximately the same rates in Conditional Positive Change and Negative Change categories and the opinion that environmental problems wouldn't change didn't continue. In view of the codes and categories after the implementation, it appears that participants had the opinion that the environment would undergo a change incorporating its entire components. In view of the codes of the category Conditional Positive Change, pre-service teachers indicated that the environmental problems could be solved, when ecofriendly behaviors such as environmental education, development of environmental awareness, effective functioning of recycling are shown in the future. Other participants expressed their opinions using pessimistic statements for 50 years from now as a result of their knowledge. The participants' statements after the implementation were as follows:

"50 years from now, water shortage will increase. Big states, which fight for oil today, will declare war against weak states." (Postimplementation Interview G)

"Because of air pollution [=pollution], everyone will have asthma [=disease], cancer [=disease]" (Post-implementation Interview D)

"If raising awareness increases, the number of activities made increases [=environmental awareness], environmental problems may be reduced. But there may be less environmental problems compared to today. But if there is no awareness raising, if the people who rule do not pay attention to the public [=State placing emphasis on its citizens], there'll be more to come. There may be a water shortage; may be this[=water shortage] will happen." (Post-implementation Interview F)

Results About Environmental Awareness

Table 7 shows the pre-service teachers' opinions about an eco-friendly person before and after the implementation. 


\section{Table 7.}

Coding and category densities of pre-service teachers' opinions about an ecofriendly person before and after the implementation

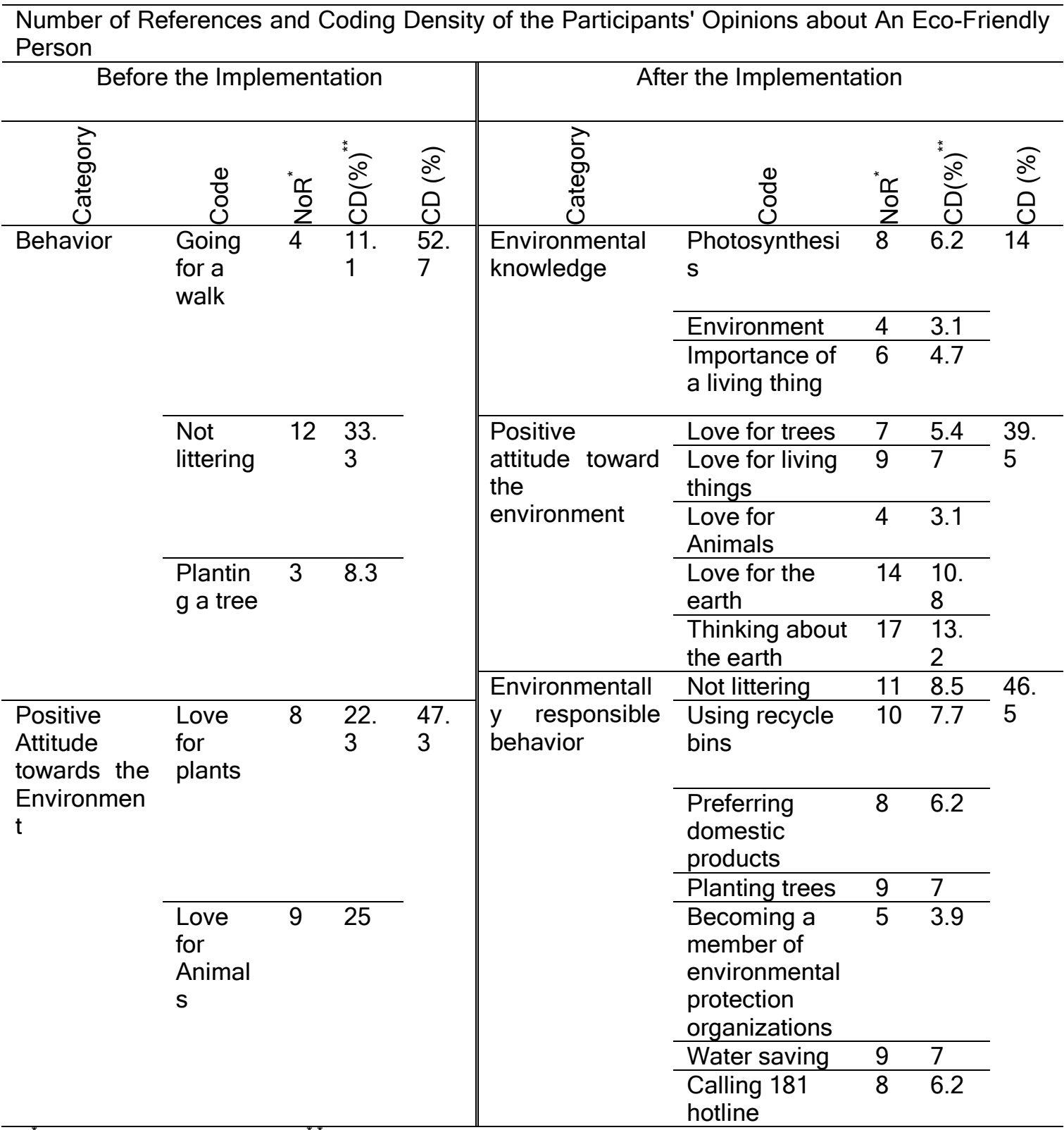

\footnotetext{
"Number of References " Coding Density
}

Pre-service teachers' opinions of an eco-friendly person before the implementation were grouped in the categories of attitude towards the environment and behavior. Codes in the behavior category reveal that the behaviors are not shown to provide a benefit to the environment. The participants thought that going for a walk in the environment or showing love for plants and animals are enough to become an eco-friendly person. It was seen that there were deficiencies in the participants' descriptions of a person with environmental awareness, i.e. an eco-friendly person. 
In view of the participants' statements about an eco-friendly person after the implementation, it is clear that they referred to environmental knowledge, positive attitude and environmentally responsible behavior. They defined an eco-friendly person as a person with environmental knowledge showing positive attitudes towards the environment with acts such as showing love for the environmental components and thinking about them, and displaying environmentally responsible behavior s to the environment. EFPAP can be said to teach the participants what an eco-friendly person means.

"An eco-friendly person is a person who goes for a walk, travels and does sports." (Pre-implementation Interview D)

"Loves cats [=love for animals], loves dogs [=love for animals]...loves the flowers in his/her home[=love for plants]." (Pre-implementation Interview J)

"I'd call a person who does everything s/he does carefully an ecofriendly person. Actually most people know what they have to do but they cannot turn this into a behavior or a habit. I'd call a person who thinks about the earth and loves the living things on the earth an eco-friendly person." (Post-implementation Interview G)

"S/he calls 181 hotline for people to take action when s/he sees an environmental problem...becomes a member of organizations protecting the environment, doing things for the environment [=becoming a member of environmental protection organizations]." (Post-implementation Interview D)

Results About The Pre-Service Teachers ' Opinions of EFPAP Activities

After the implementation, the pre-service teachers were asked to provide their opinions about the activities. Codes and categories of these opinions are given in Table 8. 
Table 8.

Coding and category densities of pre-service teachers' opinions about the implementation

\begin{tabular}{|c|c|c|c|c|}
\hline Category & Code & NoR ${ }^{*}$ & $C D^{* *}(\%)$ & CD (\%) \\
\hline \multirow{8}{*}{$\begin{array}{l}\text { Behavioral } \\
\text { Changes }\end{array}$} & Power saving & 4 & 2.9 & \multirow[t]{8}{*}{55.8} \\
\hline & Calling the municipality & 6 & 4.4 & \\
\hline & Reducing garbage & 13 & 9.6 & \\
\hline & Using recycle bins & 8 & 5.9 & \\
\hline & Using energy saving bulbs & 7 & 5.1 & \\
\hline & Using waste battery bins & 6 & 4.4 & \\
\hline & Recyclable material & 14 & 10.3 & \\
\hline & Reuse: & 18 & 13.2 & \\
\hline \multirow{4}{*}{$\begin{array}{l}\text { Attitude } \\
\text { Changes }\end{array}$} & Awareness & 8 & 5.9 & \multirow[t]{4}{*}{25.8} \\
\hline & $\begin{array}{l}\text { Interest in news about the } \\
\text { environment }\end{array}$ & 10 & 7.4 & \\
\hline & Happiness & 2 & 1.5 & \\
\hline & $\begin{array}{l}\text { Concern for the future of the } \\
\text { environment }\end{array}$ & 15 & 11 & \\
\hline \multirow{3}{*}{$\begin{array}{l}\text { Environmental } \\
\text { knowledge } \\
\text { Changes }\end{array}$} & $\begin{array}{l}\text { Knowing the effects on the } \\
\text { environment }\end{array}$ & 10 & 7.4 & \multirow[t]{3}{*}{18.4} \\
\hline & Knowing precautions & 13 & 9.5 & \\
\hline & Knowing the importance of people & 2 & 1.5 & \\
\hline
\end{tabular}

"Number of References " Coding Density

Pre-service teachers' opinions of the activities and the course were categorized according to the changes in behaviors, attitudes and environmental knowledge they referred to. It is clear that the participants gained knowledge about negative effects on the environment and possible precautions that can be taken against such effects. They developed an awareness of the environment, happiness because of developing love for the environment and concern about the future of the environment, and showed signs of positive attitudes towards the environment. It is seen that the participants acquired knowledge about environmental problems and they developed changes in behavior about prevention of environmental pollution. The pre-service teachers stated that they showed behaviors of saving, reuse and recycling, which can be an indicator of to what extent the objectives of the implementation have been met. The implementation can be said to be effective in raising eco-friendly pre-service teachers.

"I was greatly interested in energy saving bulbs. Energy saving bulbs are more expensive but you can use them for longer and cause less damage. For example, I looked at the bulb in my room and changed it."(Post-implementation Interview D)

"Our house has no insulation. We were using too much gas for heating. We, me and my housemate, talked that we should use less gas [=energy saving]." (Post-implementation Interview C)

"I'm happy when I see a forest; when I see it, I know that I should do my best to protect it."(Post-implementation Interview H)

"In the past, I had no interest in news about the environment; now I most definitely read any news about the environment on a newspaper or a magazine" (Post-implementation Interview J) 


\begin{abstract}
"Everybody should be aware that they live in the environment and not only them but also many people, living and nonliving things live in it and act accordingly [=awareness]. They should know that any damage caused by them will not only affect them but everyone around them." (Post-implementation Interview K)
\end{abstract}

After I learned from where a product has come from and the amount of damage caused to the environment in the process, I check the country of origin of every product [=awareness]. (Post-implementation Interview A)

\begin{abstract}
"Many conferences and congresses were held, decisions were passed but environmental pollution cannot be prevented, global warming cannot be prevented. I'm sometimes terrified about the future of environment [=concern for the future of the environment]."(Post-implementation Interview B)
\end{abstract}

\title{
Discussion, Conclusion and Suggestions
}

In the light of the findings obtained in the study, the effects of the Eco-Friendly Person Activity Package, developed to raise environmental awareness in the pre-service teachers, on developing environmental knowledge, attitudes and environmentally responsible behavior $s$ towards the environment in the participants were investigated. In this context, the participants' pre- and post-implementation opinions about the environment, environmental problem and characteristics of an eco-friendly person were examined to identify the effectiveness of EFPAP. Their opinions of the implementation were also studied after the implementation.

According to the study findings, there were deficiencies in the participants' descriptions of the environment and their thoughts about environmental problems before the implementation. Most of the pre-service teachers considered the environment as one only consisting of the living things they can see around them and had no knowledge about the components of the environment and that such components are in a balance by interactions, and limited environmental problems with events causing damage to human beings. The participants, who stated that environmental problems only cause damage to human beings, showed characteristics of an anthropocentric individual (Erten,2007; Erten and Aydoğdu, 2011). Pre-service teachers had negative thoughts about the future of environmental problems in general. What is interesting here is that they didn't think that what individuals could do can have positive effects on environmental problems. In other words, before the implementation, the participants saw the environment independently from themselves and could not think that behaviors useful for the environment can have positive effects on the environment. These findings are consistent with those reported by previous studies in the literature stating that university students and teachers do not have adequate knowledge about the environment and the components of the environment (Desjean-Perrota, Moseley, Cantu, 2008; Erol and Gezer, 2006;Yılmaz, Morgil, Aktuğ and Göbekli, 2002;Sama, 2003; Zak and Munson, 2008). The fact that individuals have negative thoughts about the future of the environment is in contradiction with the objective of raising individuals who are optimistic about the future and know that the problems can be resolved by showing effort, one of the basic goals of education (Erten, 2003). This finding was interpreted as evidence of lack of environmental education.

After the implementation, the participants' thoughts about the environment, environmental problem and future environmental problems changed. The pre-service teachers referred to nonliving things, the relationship between the things and the balance in the environment while describing the environment. This indicates that their level of ecological knowledge about the environment improved. The implementation 
was also found to deepen the participants' descriptions of environmental problems. Before the implementation, the pre-service teachers defined an environmental problem as visible situations which directly affect them, and after the implementation, they described environmental problems in detail. The participants became aware of the effect of human beings on the environment and defined behaviors of individuals causing damage to the environment as environmental problems. When the effect of the implementation on the opinions of future environmental problems is studied, it appears that basic level of reasoning about potential environmental problems 50 years from now was replaced by a variety of realistic ideas. It is noticeable in terms of the results of the study that the participants mentioned possibility of positive developments provided that individuals do what is required to resolve possible environmental problems in the future. This suggests that the participants showed signs of becoming an ecocentric individual. Ecocentric thought, which is based on protection of the environment in an unselfish way, ensures that environmentally responsible behavior $\mathrm{s}$ are more permanent (Erten, 2007; Erten and Aydoğdu, 2007). Therefore, it is very important that individuals have an ecocentric environmental understanding. This education provided improvements in the individuals' descriptions of the environment. This study is in good agreement with previous studies which showed that when educational activities about the environment provided to individuals were increased, their environmental knowledge also increased (Keleş, Uzun and Varnaci-Uzun, 2010; Poudel, Vincent, Anzalona, Huner, Wollard, Clement, DeRamus, and Blakewood, 2005; Şahin, Cerrah, Saka and Şahin, 2004).

Pre-service teachers were questioned about their knowledge on the characteristics of an eco-friendly person in order to identify their descriptions of environmental awareness before the implementation. They were asked to define environmental knowledge, positive attitude and environmentally responsible behavior, which are the three dimensions of an eco-friendly person (Erten, 2005). Before the activity package, the participants envisaged an eco-friendly person as a person who spends time inside the environment and shows love for street animals and houseplants. When the participants' opinions of an eco-friendly person were studied after the implementation, it was seen that they referred to ecological information about the environment, actions to protect the environment and attitudes towards the environment. The participants, who made a very limited description of an eco-friendly person before the implementation, made clear and detailed descriptions of an eco-friendly person after the implementation, which indicates that EFPAP was effective in introducing the concept of an eco-friendly person and requirements of becoming one. Moreover, their references to recycling of wastes and water saving indicate that they had the concept of an ecocentric eco-friendly person. Based on these findings related to the description of an eco-friendly person, environmental education provided as a whole can be said to be effective in raising awareness about attitudes and behaviors towards the environment in pre-service teachers. (Chatzifotiou, 2006; Meichtry and Smith, 2007; Volk and Cheak, 2003). Moreover, the participants' increased knowledge about the environment was found to be effective in increasing their attitudes and behaviors towards the environment (Tikka, Kuitunen and Tynys, 2000). It is very important to know the definition of an eco-friendly person and act as one. Only a teacher showing eco-friendly behaviors can raise awareness about the environment in new generations (Güler, 2009, Haktanır, 2007; Lewin-Benham, 2006; Malone and Tranter, 2003; Phenice and Griffore, 2003).

In view of the participants' opinions about EFPAP, they were found to use positive statements about the process. The pre-service teachers stated that they enjoyed carrying out the activities and being involved in noncurricular activities. Changes in the 
participants themselves and their environment after the implementation included increased environmental knowledge, changes in attitudes such as happiness about the environment and concern about the future of the environment and, behaviors aiming to protect the environment and prevent problems. EFPAP can be said to change the individuals' knowledge and attitudes, which in turn are transformed into behaviors about the environment. The valuable result, which the study aimed throughout the implementation process, was that the environmental education manifested itself in the individual as a behavior useful for the environment. A teacher who is unaware of environmental problems, does not have adequate knowledge and experience, has no experience of the environment and does not show environmentally-conscious behaviors cannot reach the level of environmental education s/he aims in his/her students (Atasoy and Ertürk, 2008; Atasoy, 2015). An eco-friendly teacher can be effective in providing his/her students with information about the environment and raising awareness in them (Güler, 2009, Haktanır, 2007; Lewin-Benham, 2006; Malone and Tranter, 2003; Phenice and Griffore, 2003). It is thought that maintaining an educational understanding which makes individuals face the real environment in a certain arrangement and shows them that they are the lead actors (Erten, 2007) in environmental problems, which is a worldwide problem beyond what they see, was effective. These findings are in good agreement with previous studies which reported that when the individuals are provided with environments where they acquire knowledge by interacting with the environment, reflect on environmental problems outside the classroom and do something for the environment, more effective results can be achieved (Karataş and Arslan, 2012; Meydan, Bozyiğit and Karakurt, 2012; Ozaner, 2004; Payne, 2006; Phenice and Griffore, 2003).

In general, the study results suggest that the Eco-Friendly Person Activity Package, which was developed to raise examples of eco-friendly teachers and integrated into Environmental Education Course, can be said to be effective in reaching its targets. Providing environmental education in a planned manner is seen to enable observation of eco-friendly behaviors in students in a quicker way (Uluçınar-Sağır,Aslan \& Cansaran, 2008). It is a fact that it is not possible to provide environmental education which may resolve environmental problems by only using a book full of environmental knowledge and observing the environment seen through the window of a classroom. The future of the environment requires raising individuals who were educated using the environment, live the environment and are equipped with knowledge, attitudes and behaviors to keep the environment alive. Repeating this study, which was conducted with students from a department during a semester, with pre-service pre-service teachers from various departments in a greater scale may contribute to understanding the effectiveness of EFPAP. Deficiencies in knowledge, attitudes and behaviors about the environment of the students before the implementation were ascribed to the fact that they didn't receive any environmental education during previous six terms of their undergraduate study. This result is evidence of the lack of environmental education, which is a problem with international scale, and causes concern. Based on this, it is thought that there should be curricular activities in which environmental education is provided using alternative implementations and which doesn't limit environmental education with a single course. 


\section{References}

Atasoy, E. \& Ertürk, H. (2008). İlköğretim öğrencilerinin çevresel tutum ve çevre bilgisi üzerine bir alan araştırması. Erzincan Üniversitesi Eğitim Fakültesi Dergisi, 10(1), 105-122.

Atasoy, E. (2015). Insan-doğa etkileşimi ve çevre eğitimi. İstanbul: Sentez Yayıncılık.

Chatzifotiou, A. (2006). Environmental education, national curriculum and primary school teachers. Findings of a research study in england and possible implications upon education for sustainable development. The Curriculum Journal, 17(4), 367-381.

Cohen, L., Manion, L., \& Morrison, K. (2007). Research methods in education (6th ed.). London, U.K: Routledge.

Coolican, H. (2009). Research methods and statistics in psychology $5^{\text {th }}$ edition. London: Hodder Education.

Çağlar, Y. (2011). Çevreleme çevre üzerine sessiz tartışmalar. Ankara: İmge Yayınevi.

Desjean-Perrota, B., Moseley, C., \& Cantu, L. E. (2008). Pre-service teachers' perceptions of the environment: Does ethnicity or dominant residential experience matter?.Reports $\&$ Research, $39(2), 21-31$.

Erol G. H. \& Gezer, K. (2006). Sınıf öğretmenliği öğretmen adaylarının çevreye ve çevre sorunlarına yönelik tutumları. International Journal of Environmental and Science Education, 1(1), 65-77.

Erten, S. (2003). 5. Sınıf öğrencilerinde "çöplerin azaltılması” bilincinin kazandırılmasına yönelik bir öğretim modeli. Hacettepe Üniversitesi Eğitim Fakültesi Dergisi, 25, 1-13.

Erten, S. (2004). Çevre eğitimi ve çevre bilinci nedir, çevre eğitimi nasıl olmalıdır?. Çevre ve insan Dergisi, 65(66), 1-13.

Erten, S. (2005). Okul öncesi öğretmen adaylarında çevre dostu davranışların araştırılması. Hacettepe Üniversitesi Eğitim Fakültesi Dergisi, 28, 91-100.

Erten, S. (2007). Insights to ecocentric, anthropocentric and antipathetic attitudes towards environment in diverse cultures. Eğitim Arastırmaları-Eurasian Journal of Educational Research, 33, 141-156.

Erten, S. \& Aydoğdu, C. (2011). Türkiyeli ve Azerbaycanlı öğrencilerde, ekosentrik, antroposentrik ve çevreye karşı antipatik tutum anlayışları. Hacettepe Üniversitesi Eğitim Fakültesi Dergisi, 41(41). 158-169.

Erten, S. (2012). Türk ve Azeri öğretmen adaylarında çevre bilinci. Eğitim ve Bilim, 37(166), 88100.

Farmer, J., Knapp, D., \& Benton, M.G. (2007). An elementary school environmental education field trip: Long-term effects on ecological and environmental knowledge and attitude development. The Journal of Environmental Education, 38(3), 33-42.

Foster, J. M. \& Magdoff, F. (2011). Bir çevrecinin kapitalizm hakkında bilmesi gerekenler kapitalizm ve çevre üzerine bir rehber (Çev. Ö. Aksakal). İstanbul: Patika Kitap.

Güler, T. (2009). Ekoloji temelli bir çevre eğitiminin öğretmenlerin çevre eğitimine karşı görüşlerine etkileri. Eğitim ve Bilim, 34(151), 30-43.

Haktanır, G. (2007). Okul öncesi dönemde çevre eğitimi içinde: Çevre eğitimi. Türkiye Çevre Eğitimi Vakfı Yayını, 178, 11-34.

Hungerford, H.R. \& Peyton, R.B. (1994). Procedures for developing an environmental education curriculum (Series EE 22). Paris, France: UNESCO.

Johnson, E. A. \& Mappin, M. J. (2005). Environmental education and advocacy: Changing perspectives of ecology and education. Cambridge, U.K: Cambridge University Press.

Karataş, A. \& Aslan, G. (2012). İlköğretim öğrencilerine çevre bilincinin kazandırılmasında çevre eğitiminin rolü: Ekoloji temelli yaz kampı projesi örneği. Zeitschrift für die Welt der Türken/Journal of World of Turks, 4(2), 259-276.

Keleş, Ö., Uzun,, N., \& Varnacı-Uzun, F. (2010). Öğretmen adaylarının çevre bilinci, çevresel tutum, düşünce ve davranışlarının doğa eğitimi projesine bağlı değişimi ve kalıcılığının değerlendirilmesi. Elektronik Sosyal Bilimler Dergisi, 9(32), 384-401.

Kollmus A. \& Agyeman, J. (2010). Mind the gap: Why do people act environmentally and what are the barriers to pro-environmental behavior?. Environmental Education Research, $8(3), 239-260$.

Kvale, S. (1996). Interviews an introduction to qualitative research interviewing. Thousand Oaks, California: Sage Publications. 
Larkin, M., Watts, S., \& Clifton, E. (2006). Giving voice and making sense in interpretative phenomenological analysis. Qualitative Research in Psychology, 3(2), 102-120.

Lewin-Benham, A. (2006). Possible schools: The reggio approach to urban education. New York, USA: Teachers College Press.

Malone, K. \& Tranter, P. (2003). Children's environmental learning and the use, design and management of schoolgrounds. Children, Youth and Environments, 13(2), 1-30.

Mayring, P. (2000). Nitel sosyal araştırmaya giriş (Çev. A. Gümüş ve M. S. Durgun). Adana: Baki Kitabevi.

Meichtry, Y. \& Smith, J. (2007). The impact of a place-based professional development program on teachers' confidence, attitudes, and classroom practices. Reports \& Research, 38(2), 15-31.

Meydan, A., Bozyiğit, R., \& Karakurt, M. (2012). Ekoloji temelli doğa eğitimi projelerinin katılımcı beklentilerini karşılama düzeyleri. Marmara Coğrafya Dergisi, 25, 238-255.

Miles, M. B. \& Huberman, A. M. (1994). Qualitative data analysis: An expanded sourcebook (2nd ed.). Thousand Oaks, California: Sage Publications.

Ozaner, S. (2004). Türkiye'de okul dışı çevre eğitimi ne durumda? Neler yapılmalı?.V. Ulusal Ekoloji ve Çevre Kongresi 5-8 Ekim 2004 Taksim International Abant Palace, Abant İzzet Baysal Üniversitesi \& Biyologlar Derneği, Abant-Bolu. Bildiri Kitabı (Doğa ve Çevre), 67-98, İzmir: Biyologlar Derneği.

Özdemir, O. (2010). Yeni bir çevre eğitimi perspektifi: Sürdürülebilir gelişme amaçlı eğitim. Eğitim ve Bilim, 32(145), 23-38.

Palmberg, E.I. \& Kuru, J. (2000). Outdoor activities as a basis for environmental responsibility. The Journal Of Environmental Education, 31(4), 32-6.

Palmer, J. \& Neal, P. (2003). The handbook of environmental education. Taylor and Francis elibrary. Canada: Routledge.

Payne, P. G. (2006). Environmental education and curriculum theory. The Journal of Environmental Education. 37(2), 25-35.

Phenice, L. A. \& Griffore, R. J. (2003). Young children and the natural world. Contemporary Issues in Early Childhood, 4(2), 167-171.

Poudel, D. D., Vincent, L. M., Anzalona, C., Huner, J., Wollard, D., Clement, T., DeRamus, A., \& Blakewood, G. (2005). Hands-on activities and challenge test in agricultural and environmental education. The Journal of Environmental Education, 36(4), 10-22.

Sama, E. (2003). Öğretmen adaylarının çevre sorunlarına yönelik tutumları. Gazi Eğitim Fakültesi Dergisi, 23(2), 99-110.

Sanera, M. \& Shaw, J. S. (1999). Korkular değil gerçek çocuklarınız ve sizin için çevre eğitimi rehberi (Çev. V.F. Savaş). Ankara: Liberte Yayınları.

Şahin, N. F., Cerrah, L., Saka, A., \& Şahin, B. (2004). Yüksek öğretimde öğrenci merkezli çevre eğitimi dersine yönelik bir uygulama. Gazi Eğitim Fakültesi Dergisi, 24(3), 113-128.

Tikka, P. M., Kuitunen T. M., \& Tynys M. S. (2000). Effects of educational background on students' attitudes, activity levels, and knowledge concerning environment. The Journal of Environmental Education, 31, 12-19.

Yıldırım, A. \& Şimşek, H. (2006). Sosyal bilimlerde nitel araştırma yöntemleri. (6th ed.) Ankara: Seçkin Yayıncılık.

Yıldırım, C., Bacanak, A., \& Özsoy, S. (2012). Öğretmen adaylarının çevre sorunlarına karşı duyarlılıkları. Kastamonu Eğitim Fakültesi Dergisi, 20(1), 121-134.

Yılmaz, A., Morgil, İ, Aktuğ, P., \& Göbekli, İ. (2002). Ortaöğretim ve yüksek öğretim öğrencilerinin çevre, çevre kavramları ve sorunları konusundaki bilgileri ve önerileri. Hacettepe Üniversitesi Eğitim Fakültesi Dergisi, 22, 156-162.

Wilson, R. A. (1996). Environmental education programs for preschool children. Journal of Environmental Education, 27(4), 71-81.

Volk, T. L. \& Cheak, M. J. (2003). The effects of en environmental education program on students, parents, and community. The Journal of Environmental Education. 34(4), 1225.

Zak, K.M., \& Munson, B.H. (2008). An exploratory study of elementary pre-service teachers' understanding of ecology using concept maps. The Journal of Environmental Education, 39(3), 32-46. 


\title{
Çevre Bilinci Kazandırmaya Yönelik Geliştirilen Çevre Dostu Birey Etkinlik Paketine İlişkin Öğretmen Adayı Görüşleri
}

\author{
Sevcan CANDAN \\ Kastamonu Üniversitesi, Kastamonu, TÜRKIYE \\ Sinan ERTEN \\ Hacettepe Üniversitesi, Ankara, TÜRKIYE
}

\begin{abstract}
Özet
$\mathrm{Bu}$ araştırmada, öğretmen adaylarına çevre bilinci kazandırmayı, gelecekteki öğrencileri için çevre dostu örnek bir öğretmen olmalarını sağlamayı amaçlayarak geliştirilmiş Çevre Dostu Birey Etkinlik Paketi'nin, etkililiği ve bu pakete ilişkin katılımcı görüşleri araştırılmıştır. Araştırma 2014-2015 eğitim-öğretim yılı güz döneminde bir devlet üniversitesinde Çevre Eğitimi Dersi'ni alan, Sınıf Öğretmenliği 4. Sınıf öğrencilerinden 75 kişi ile gerçekleştirilmiş, çalışmaya katılan 10 öğrencinin görüşlerine başvurulmuştur. Nitel araştırma deseninde fenomenolojik (olgu bilim) bir çalışmadır. Araştırmada veriler yarı yapılandırılmış görüşme formu ve görüşmeler ile elde edilmiş, Nvivo 9 nitel analiz programı ile tümevarımcı bir yaklaşımla çözümlenmiştir. Katılımcıların uygulama öncesi ve sonrası; çevre, çevre sorunu, gelecekteki çevre sorunları, çevre dostu bireye ilişkin bilgileri sorgulanmış ve uygulama sonrası Çevre Dostu Birey Etkinlik Paketi'ne ilişkin görüşleri alınmıştır. Uygulama öncesi katılımcıların çevreye ilişkin bilgi eksiklikleri, çevre sorunlarında insanın rolünün göz ardı edildiği, gelecekteki olası çevre sorunları ile ilgili gerçekçi tahminlerde bulunamadıkları ve çevre dostu birey olma gerekliliklerini bilmedikleri tespit edilmiştir. Çevre Dostu Birey Etkinlik Paketi ile verilen çevre eğitimi sonrası katılımcılar, çevre ile ilgili ekolojik bilgilere hakim, bu bilgilerden hareketle çevre sorunlarını ve nedenlerini tanımlayabilen, gelecekte çevrenin durumunun insan davranışlarına bağlı olarak değişeceğini fark eden, çevreyi sevme ve geleceğinden endişe etme gibi olumlu tutum gösteren, çevre dostu bireyi tanımlayan ve böyle davranışlar gösterdiklerini belirten ifadelerde bulunmuşlardır. Bulgulardan hareketle; çevre dostu örnek öğretmenler yetiştirmeyi hedefleyen Çevre Dostu Birey Etkinlik Paketi'nin hedefini gerçekleştirmede etkili olduğu sonucuna ulaşılmıştır.
\end{abstract}

Anahtar Kelimeler: Çevre eğitimi, çevre dostu birey, öğretmen adayları, çevre dostu birey etkinlik paketi. 